1945-05-01

\title{
The North American species of Smilacina
}

Desma H. Galway

Brigham Young University - Provo

Follow this and additional works at: https://scholarsarchive.byu.edu/etd

\section{BYU ScholarsArchive Citation}

Galway, Desma H., "The North American species of Smilacina" (1945). Theses and Dissertations. 8057. https://scholarsarchive.byu.edu/etd/8057

This Thesis is brought to you for free and open access by BYU ScholarsArchive. It has been accepted for inclusion in Theses and Dissertations by an authorized administrator of BYU ScholarsArchive. For more information, please contact ellen_amatangelo@byu.edu. 
The North American Species of Smilacina

\author{
DESMA H. GALWAY
}

Reprinted from

"THE AMERICAN MIDLAND NATURALIST"

Vol. 33, No. 3, pp. 644-666, May, 1945

The University Press

Notre Deme, Ind. 


\title{
The North American Species of Smilacina
}

\author{
Desma H. Galway
}

\section{Introduction}

This paper is the result of a taxonomic study of the species of the genus Smilacina occurring naturally in North America north of Mexico. In the past it has been difficult to make satisfactory determinations of members of this genus from existing manuals, especially among western forms. West of the great plains the great diversity in environmental conditions has given rise to a diversity in form of the species that are widely distributed. Many of these forms have been given specific or varietal names recently, and as no comprehensive work on the genus has been done since most of these were published, it is hoped that this study will be generally helpful in identifying members of the group.

During the preparation of this work over 2500 herbarium specimens have been examined and annotated and comparative measurements made of many of these. These include either the types or specimens designated by the author of the name as typical of nearly all of the forms for which names have been published.

Specimens have been examined from all of the forty-eight states except Louisiana and Florida, also from Canada, Alaska, Mexico, Central America, and Asia. Field work has been comparatively limited. However, specific differences in the genus Smilacina have been based mostly on gross morphological characters, readily discernible in herbarium material.

\section{History}

The species now assigned to the genus "Smilacina" have been subject to considerable controversy, and in all have been published under at least thirteen different generic names.

In his Species Plantarum (17, p. 315), in 1753, Linnaeus published the genus Convallaria, which included three species now referted to $S$ milacina, and species of Maianthemum, Polygonatum, and Convallaria proper.

In 1763 Adanson published Vagnera in honor of Richard Wagner, without, however, citing species. From his description the application of the name is evident, and his was the first attempt to split Linnaeus' Convallaria into more natural, smaller groups. However his work was not given recognition at that time.

In 1790 Necker published Tovaria, citing to it the three Linnaean species later included in Desfontaine's Smilacina. However he did not publish species names as such, and his generic description was inaccurate (See Victorin, 30, p. 80), so that his work has not generally been credited. Later Ruiz and Pavon published the name Tovaria for a South American genus related to the Cap- 
paridaceae, and the name is now held valid for that group. In 1763 Adanson published the distinct name Tovara for a genus in the Polygonaceae.

In 1807 Desfontaines published the name Smilacina (the name meaning Smilax-like). His generic description was brief but accurate. He included in the genus Linnaeus' three species, also the present Clintonia umbellata, based on Michaux's Convallaria umbellata (Fl. Boreal. Amer. 1, p. 202), and a fourth member similar to Smilacina amplexicaulis which he called $S$. ciliata.

During the fore part of the nineteenth century, botanical exploration in Central America and Asia brought to light a number of other affiliated species. In 1850, Kunth divided the expanded genus into three genera, which he named Asteranthemum, Jocaste, and Medora. Occasionally specimens of North American forms are still found in herbaria labeled as Asteranthemum.

In 1821 Link published $S$. racemosa and $S$. stellata under Maianthemum of Wiggam. This name is now confined to a closely related genus, distinguished from Smilacina by the 2- rather than 3-merous flowers.

In 1794 Moench published Polygonastrum; in 1819 Rafinesque published Sigillaria and Styrandra; in 1866 Salisbury published Neolexis; all names of questionable application and all but Polygonastrum antedated by Smilacina.

In 1875 Baker revived Tovaria of Necker and republished all the species he recognized under this name. In 1888 and 1889 Greene and Britton republished the species then known, at least as to North American forms, under Unifolium, including them with $U$. bifolium. Referring to Desfontaine's original publication of Smilacina, Greene regarded $S$. umbellata as the type species of the genus, and hence referred the species of Clintonia to Smilacina.

In 1894 Morong brought to light Adanson's publication of Vagnera and republished all of the North American species under this name. Vagnera was held as the accepted name of the genus by proponents of the "American Code" from that time on. In 1905, however, Smilacina was placed on the list of nomina conservanda by the Vienna Congress on the basis of long usage.

During the latter part of the 19th century, Nuttall (published by Baker), Greene, and Rydberg proposed several new species, mainly from western North America. Since the beginning of this century taxonomic work on the North American species has been confined to the naming of a few new varieties and forms. These will be discussed in detail later.

\section{Economic Importance}

Smilacina racemosa and $S$. stellata, also $S$. paniculata of Mexico and Central America, are occasionally cultivated for ornamental use because of their graceful habit, attractive, bright green foliage, and clusters of flowers and fruit.

None of the species have any forage value although they are not known to contain any poisonous principle. The "Palatability Tables for Region 4" in the Western United States, compiled by the U. S. Forest Service, list the palatability of "Vagnera" species as " 5 ," a very low rating. In certain areas in New Mexico and perhaps elsewhere, increases in abundance of Smilacina 
stellata is regarded as evidence of overgrazing. (See Sampson, 26, pp. 36-37, 39.)

The berries are not agreeable in flavor to man, although they appear to be eaten by certain birds. Those of $S$. trifolia are said to contain an active cathartic and were used as such by early explorers in subarctic regions. (See Victorin, 30, p. 86.)

That the West Coast Indians found a use for the plant is indicated by the following note taken from a herbarium sheet of $S$. stellata belonging to the Field Museum. The plant was collected in California "Near Monolith, Piute Mts., Kern Co. Maurice L. Zigmond 104, July 7, 1937. $4400-5500 \mathrm{ft}$.

'Pa'ro'ra ba. Plant growing by water. Has green berries striped purple. Root is mashed and put in stream to stun fish. Fish float to top of water and are caught in yadaci (winnower), thrown to bank."

\section{Evolution and Relationships}

Smilacina is a member of the tribe Polygonatae in the family Liliaceae. (See Hutchinson ,14, p. 94.) The tribe is characterized by having an underground rhizome and a leafy aerial stem, also by the fruit, which is always a berry. Smilacina is distinguished from the other genera of the tribe by its simple aerial stem bearing several alternate leaves; its single, terminal inflorescence which may be either racemose or paniculate; and its six distinct perianth segments. Our species have white or greenish white flowers. The flowers of some Central American and Asiatic species are rose, purple, or cream-colored.

The nearest relative of Smilacina is probably Maianthemum, which was perhaps derived from the former genus by a reduction in the number of flower parts from six to four. Disporum, with branching stem and few-flowered, terminal inflorescence, also appears to be closely related.

Smilacina is considered as primitive in having distinct perianth-segments and a many-flowered inflorescence. It is advanced in its simple stem and single, terminal inflorescence. The most primitive of Smilacina species is probably $S$. racemosa, as evidenced by its wide distribution near the geographic center of the range of the genus and its unspecialized, paniculate inflorescence. Other species seem to have arisen in the four following ways: 1, the development of a more vigorous habit of growth (mainly tropical forms, $S$. paniculata, $S$. thyrsoidea); 2, the development of pigmented flowers ( $S$. Japonica, S. Salvinii); 3 , the reduction of the inflorescence from a panicle to a simple raceme ( $S$. stellata, $S$. trifolia); 4 , the adaptation to specialized environments ( $S$. trifolia in peat bogs, $S$. Salvinii as an epiphyte).

It is interesting to trace among specimens still in existence the process whereby the paniculate inflorescence may have developed into the racemose type. In $S$. racemosa, the upper branches of the panicle frequently have the branch axis so shortened that the flowers appear to spring in an umbelliform cluster from the main axis. Specimens are occasionally seen, mostly from the South Central United States (New Mexico to Georgia), which have all branches so shortened. (Such a form was the type of Greene's S. glomerata ined.) 
In S. flexuosa of Central America is found a similar condition; the inflorescence is "racemose," but several pedicels arise from each node of the axis, or at least from some of them. In this species, the pedicels are very long and the flowers much larger than in $S$. racemosa; consequently there is no danger of confusing the two species. $S$. flexuosa probably arose directly from a form like $S$. paniculata, another Central American form, which except for its long pedicels and general robust habit is similar to typical $S$. racemosa.

In $S$. daburica of eastern Asia only a few of the nodes of the inflorescence bear more than one flower. In our $S$. stellata, this condition reaches its ultimate development, the inflorescence being strictly racemose. Even in this species, however, an occasional specimen is encountered bearing two flowers at one or more of the lower nodes.

S. Japonica, of southeastern Asia and Japan, and perhaps other species also, may have the inflorescence either branched or simple. Thus it will be seen that in the genus Smilacina, the terms "racemose" and "paniculate" may be only relative in their application to the description of the inflorescence, and cannot always be relied upon as a positive means of identifying species.

$S$. trifolia of subarctic regions in North America and Siberia is probably a reduced offshoot from $S$. stellata. It is distinguished by its lower stature, fewer leaves, and specialized habitat, being found only in cold, acid bogs.

\section{Taxonomy \\ Smil.ACINA}

Herbaceous perennials from creeping, scaly rootstocks; aerial stems simple, leafy; leaves alternate, simple, entire, lanceolate to ovate or cordate, sessile or petioled; inflorescence terminal, racemose or paniculate; perianth-segments distinct, 6; stamens 6, borne at the base of the perianth-segments; anthers versatile, dehiscing inwardly; ovary 3-celled; styles 3, distinct or united; ovules 2 in each cell of the ovary; fruit a round or 3-lobed berry, 1-6-seeded.

About 23 species, only 2 of which are confined to temperate North America and a third is found in both North America and Northern Siberia. Of the remainder, 7 are in Mexico and Central America, 8 in Eastern Asia and Japan, 4 in the Himalayan Region, and 1 in Arabia.

Plants mostly of moist soil in woodlands. Some tropical American species are epiphytic.

\section{Citation of Specimens}

No attempt has been made to cite collections showing complete distribution of each form. This is shown on the accompanying distribution maps. Rather it has been the aim to select some of the more interesting specimens, including "types" and unusual forms. Also included are a wide range of representative forms which were used in the biometrical studies.

The herbaria containing the cited specimens are designated by the following key:

Brigham Young University, Provo, Utah, "BY"

Field Museum of Natural History, Chicago, "FM"

Gray Herbarium of Harvard University, Cambridge, Mass., "GH"

Missouri Botanical Garden, St. Louis, Mo., "MBG" 
University of Montreal, Montreal, Quebec, "UM"

Herbarium of Marie-Victorin, Montreal, Quebec, "MV"

New York Botanical Garden, "NY"

Herbarium of Pomona College, Claremont, Calif., "PC"

U. S. National Herbarium, Washington, D. C., "US"

Rocky Mountain Herbarium, Laramie, Wyoming, "RM."

\section{Key to North American Species}

Inflorescence paniculate.

Leaves abruptly long-acuminate, distinctly petioled, spreading

Leaves merely acute or very short-acuminate, usually somewhat clasping by the sessile or wing-petioled base, usually ascending

1a. S. racemosa var. amplexicaulis

Inflorescence racemose.

Leaves more than 4 , sessile and abruptly narrowed at the base.

Leaves not fleshy; plants of moist soil in open woodlands.

Leaves fleshy; plants maritime, of marshy areas. 2a. S. stellate var, crassa

Leaves $2-4$, tapering gradually to the somewhat sheathing base.

3. S. trifolia

\section{Smilacina racemosa (L.) Desf. Ann. Mus. Paris 9:53. 1807}

Rootstock stout; stem erect, arcuate or spreading, usually puberulent at least in inflorescence, more or less flexuous, $30-70 \mathrm{~cm}$. high; leaves lanceolate to elliptic, usually broadest at the middle, long acuminate or tailed at the apex, distinctly petioled and spreading, distichous, $2-7 \mathrm{~cm}$. wide, $6-18 \mathrm{~cm}$. long, distinctly veined, usually puberulent; inflorescence many-flowered, $3-13 \mathrm{~cm}$. long, $1-8 \mathrm{~cm}$. broad, with 5-20 branches; perianth-segments white or greenish, 1-2 $\mathrm{mm}$. long, about $.5 \mathrm{~mm}$. wide; stamens exceeding the perianth segments, 1.5 . $3 \mathrm{~mm}$. long, the anthers yellow, the filaments more or less inflated; style .3-1 $\mathrm{mm}$. long; ovary .7-1.5 mm. long; berry globose, about $5 \mathrm{~mm}$. in diameter, at first mottled red and green, later turning red or occasionally purple throughout.

Frequent in shady woods and forests in fairly moist soil throughout southern Canada and the United States, with the probable exception of Florida, Louisiana, and certain states of the intermountain West. In the latter region it is largely replaced by the variety amplexicaulis. It is absent in the plains region except along watercourses, and in the desert regions of the west is found only in the mountains. It is also found in the mountains of Chihuahua and in southern Alaska. (Fig. 1.)

This species is very variable in the size, shape, and surface texture of all its parts and has consequently been divided into a number of species and varieties. Only one of these has been retained. This conclusion was reached after making first a series of preliminary observations, comparing 35 specimens, including the types of most of the doubtful forms, comparing them on 36 characters which had or might have been cited to indicate specific or varietal differences. Those characters which from this comparison appeared significant, or which had been most stressed in literature, were then compared in large series of specimens. Among these may be mentioned leaf shape; length of petals, style, and peduncles; and shape, size, and density of inflorescence. The results of these studies are discussed later. 
Doubt as to the validity of many of the named forms has been expressed by other authors. (See St. John, 25, pp. 95-97.) Index Kewensis, which does not list varieties, does not recognize any of the species.

Convallaria racemosa L. Sp. Pl. 315. 1753.

Tovaria racemosa Neck. Elem. 3:190. 1790. (Name only) Based on C. racemosa L. Maianthemum racemosum Link, Enum. pl. Hort. Berol. 1:343. 1821. Based on C. racemosa $\mathrm{L}$.

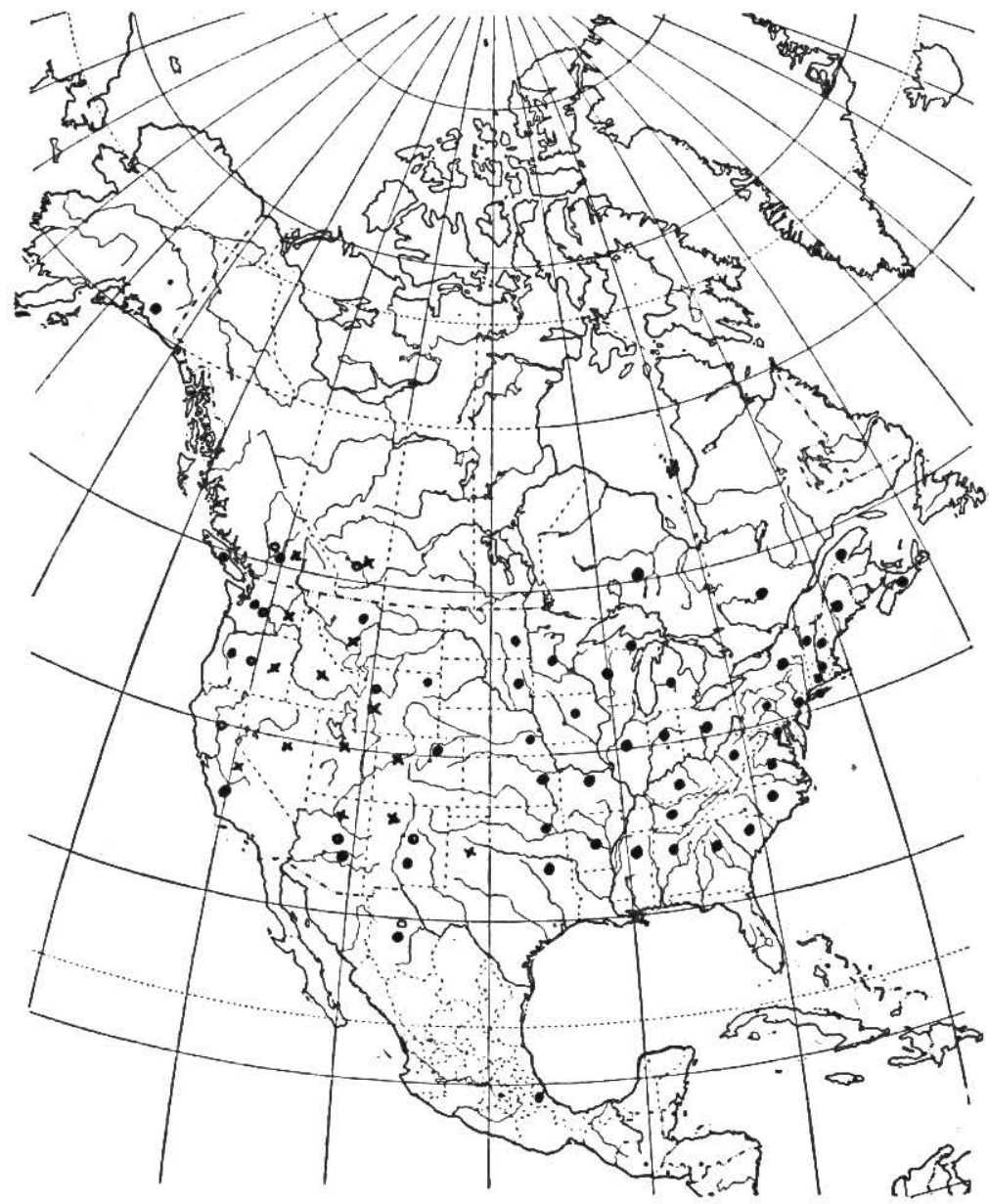

Fig. 1.- - Distribution of Smilacina racemosa (L.) Desf.

$\times$ Distribution of Smilacina racemosa (L.) Desf. var. amplexicaulis (Nutt.) S. Wats.

- Distribution of intergrading forms of Smilacina racemosa, and va. amplexicaulis. 
Unifolium racemosum Britton, Trans. N. Y. Acad. Sci. 8:74. 1889. Based on C. racemosa L.

Vagnera racemosa Morong. Mem. Torr. Bot. Club 5:114. 1894. Based on C. racemosa L.

Smilacina racemosa (L.) Desf. var. typica Fernald, Rhodora, 40:407. pl. 512. 1938.

Smilacina ciliata Desf. Ann. Mus. Paris 9:53. 1807.

Vagnera brachypetala Rydb. Bull. Torrey Club 28:268. 1901, as to type specimen.

Vagnera australis Rydb. in Small, Fl. S. E. U. S. 270, 1328. 1903.

Smilacina racemosa forma foliosa Victorin, Contrib. Lab. Bot. Univ. Montreal, $14: 15$. fig. 1. 1929.

Smilacina racemosa (L.)Desf. var. cylindrata Fernald, Rhodora 40:406. 1938.

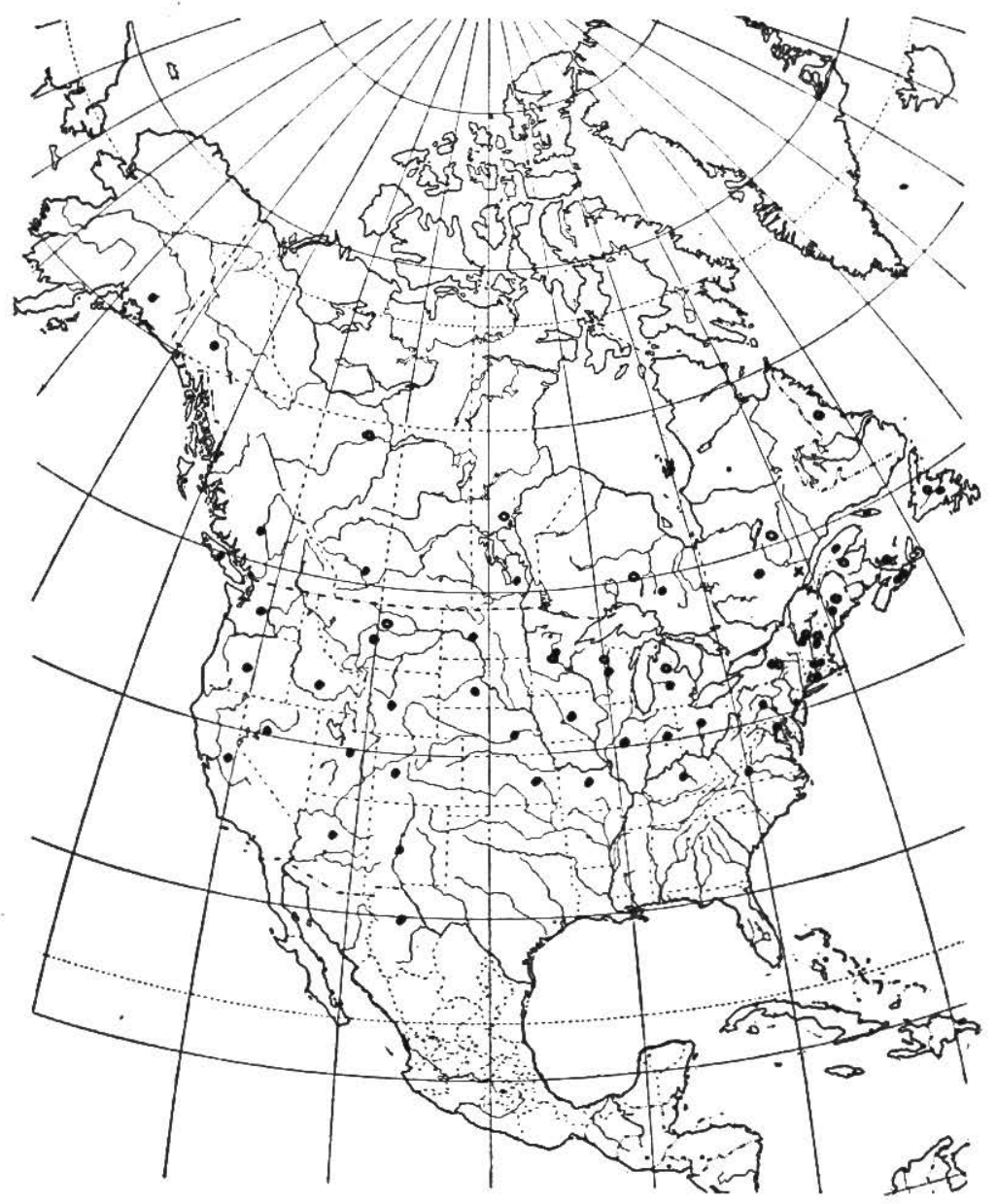

Fig. 2.- - Distribution of Smilacina stellata (L.) Desf.

$\times$ Distribution of Smilacina stellata (L.) Desf. var. crassa Victorin.

- Distribution of Smilacina trifolia (L.) Desf. 
The basis for elimination of each of the synonyms as distinct species or varieties follows:

Smilacina ciliata Desf. In his description, Desfontaines, although he states that this species is "tres distincte" gives no characters which would serve to distinguish it from typical $S$. racemosa. The height of this species is described as only $3.6 \mathrm{~cm}$., but this is probably a typographical error, $\mathrm{dm}$. being meant rather than $\mathrm{cm}$.

The illustration shows an abnormally bifurcate and trifurcate panicle, and since this condition is not found in nature in the genus, it is generally believed to be an interpolation by the artist. It is also believed that this species was founded upon a cultivated form which may have differed considerably in appearance from the wild plant, and which now may no longer be in existence. (See Fernald, 8, pp. 404-407.)

Vagnera brachypetala Rydb. Rydberg describes this species as having unusually short petals and purple, rather than typically red fruits. Of the five specimens he cites as representative, only one, the type, is in fruit. It is impossible to determine the length of the petals on this specimen. It has the longpetioled, long-acuminate leaves of typical $S$. racemosa.

Of the other four, the perianth segments range from about 1 to $1.5 \mathrm{~mm}$. in length (the range of the species is $1.2 \mathrm{~mm}$.), and the leaves of one are nearer the var. ampexicaulis. None of the specimens mentioned in the original description were collected by Rydberg, nor does he mention having seen the plant in the field.

Other herbarium specimens which have been referred to this species range from extreme amplexicaulis to typical racemosa, and have perianth-segments from 1 to as much as $2 \mathrm{~mm}$. long. Few of them are fruiting, and in these, the herbarium specimen may appear to be either red or purple.

As the color of the fruit may depend upon the degree of maturity of the plant and the $\mathrm{pH}$ of the soil in which it is grown, however, it alone can hardly be regarded as a specific or even varietal character. It is also impossible to tell with certainty the color of the fruit from a herbarium specimen.

Vagnera australis Rydb. Rydberg based this species on 3 herbarium specimens in the New York Botanical Garden collected in Alabama and Georgia. $\mathrm{He}$ lists as key characters the following:

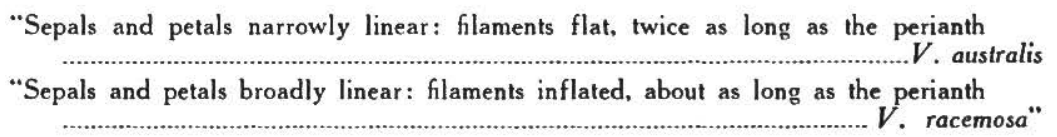

He also describes $V$. australis as being more slender and having relatively narrower leaf blades.

The perianth-segments on the cited specimens measure about $.3 \mathrm{~mm}$. in width, as compared with the average of $.5 \mathrm{~mm}$. for the species. The anthers also appear to be less inflated, and the plants are smaller than average specimens, the stems especially being slender $(1.5-3 \mathrm{~mm}$. as compared with the 
average of $5 \mathrm{~mm}$.). The other characters which Rydberg mentions as being distinctive - relative length of filaments and petals and relative width of leaves -are found to be about the same on the $V$. australis specimens as the average for the group. Other specimens collected at the type locality appear typical of S. racemosa.

The only basis for a new species or variety seems to lie in the size of some of the parts, in which there is wide variation and complete intergradation with the typical form of the species. For further discussion of the status of $V$. australis, see the treament of $S$. racemosa var. cylindrata, below.

Smilacina racemosa forma foliosa Victorin. Throughout the range of the species is found sporadically a form which has inflorescence sessile in the axil of the uppermost leaf. This is usually found in large, vigorous specimens and probably results from the development of the bractlet subtending the lowermost branch of the panicle into a leaflike structure. Rarely one or two bracts within the panicle are also enlarged. This development is also met with occasionally in the var. amplexicaulis.

Smilacina racemosa (L.) Desf. var. cylindrata Fernald. Fernald divided the bulk of the species into two varieties, a northern and a southern form, based on the relative vigor of the plants, size and shape of the panicle, and length of the peduncle. His summary of the distinguishing characters follows:

“Northern Series. Stem up to $1 \mathrm{~m}$. high; larger leaves of mature plants $1-2.5 \mathrm{dm}$. long. 3.5-9.5 cm. broad; panicle sessile or on a peduncle usually less than $1 / 2$ its length. ovoid to pyramidal, $0.7-1.7 \mathrm{dm}$. long, $3-10 \mathrm{~cm}$. in diameter, $3 / 8-3 / 4$ as broad as long, its longer branches 2-6 cm. long and with 8-24 flowers." = var, typica.

"Southern Series. Stem rarely $7.5 \mathrm{dm}$. high: larger leaves of mature plants 0.85 $1.7 \mathrm{dm}$. long, $3.5-6 \mathrm{~cm}$. broad; peduncle $1 / 2-11 / 4$ as long as the nearly cylindric panicle ; the latter 4.5-8.5 (rarely 13) cm. long, $1.5-3 \mathrm{~cm}$. in diameter, $1 / 4-3 / 8$ as broad as long, its longest branches $1-2.5 \mathrm{~cm}$. long, 6-10 flowered." = var. cylindrata.

He lists the range of both varieties by states, and says that in the region in which the ranges overlap, transitional forms are frequent.

The following table was constructed as a result of the examination and measurement of 168 specimens in the herbarium of the Missouri Botanical Garden, with reference to these characters cited by Fernald, and also those mentioned by Rydberg in describing Vagnera australis, included because it would be considered an extreme form of Fernald's var. cylindrata, the name he gives to the southern series, except for the rather short peduncle on the type specimen.

States listed under the heading "Northern Series" are those in which, according to Fernald, only var. typica is found; according to the same author, var. cylindrata is confined to the states listed under "Southern Series," while in the "Transitional" series intergrading occurs.

Examination of this table does reveal a tendency for plants in the northern portion of the range to average somewhat more vigorous habit of growth than those in the southern portion. However even allowing for the possibility that Fernald's statement as to geographical distribution might not be entirely accu- 
TABLE 1.-Distribution of 3 named forms of Smilacina racemosa, with intergrades.

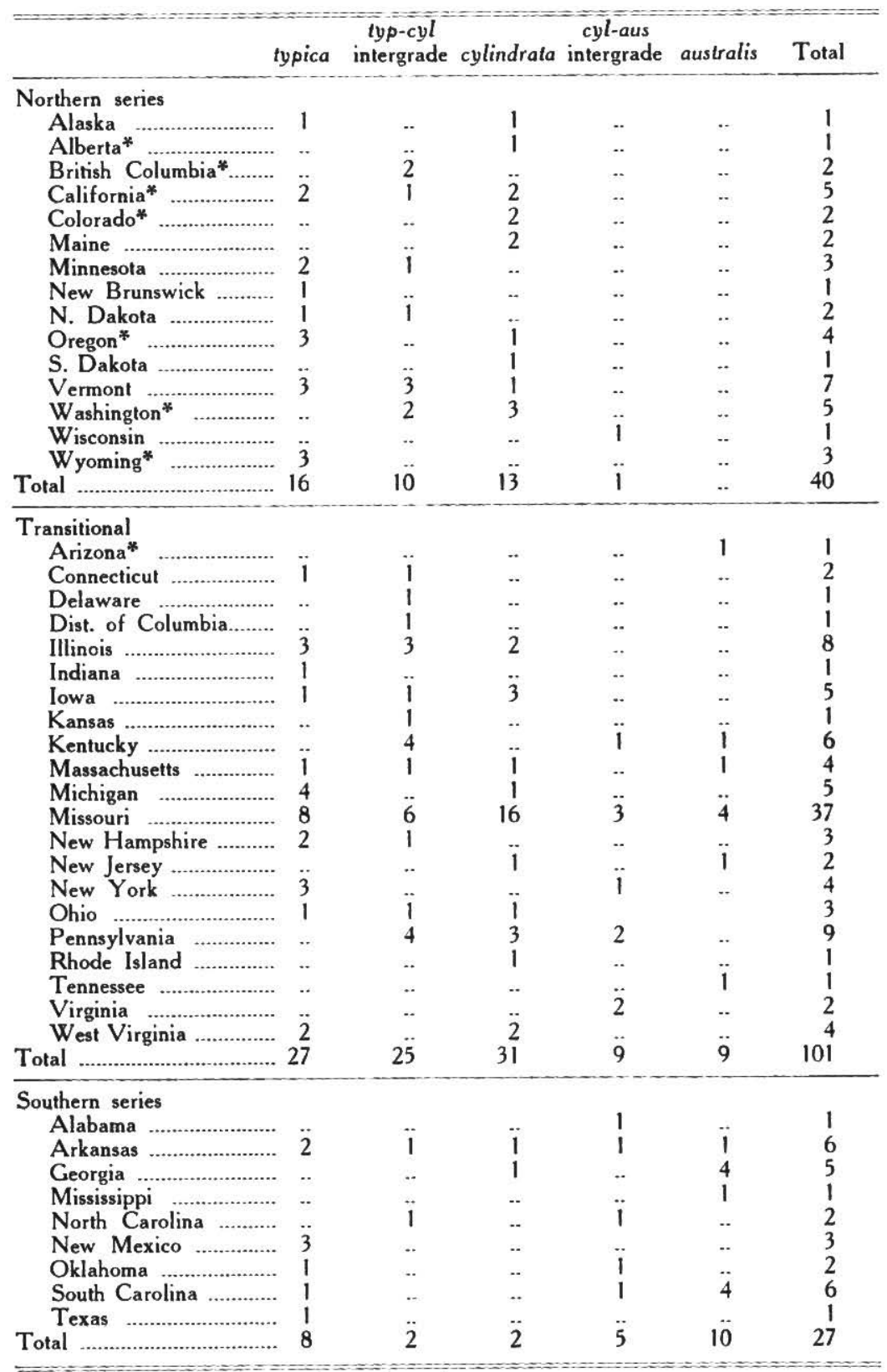

* States in which var. amplexicaulis is also present. 
rate, the statistics do not seem to warrant retaining either his var. cylindrata or Rydberg's Vagnera australis. This tendency for larger size of plants as one progresses northward along the range is found in many species of plants in the United States.

\section{Selected Specimens}

Alabama: Auburn, April 22, 1896, Earle \& Underwood (NY).

Alaska: Alaskan Boundary Survey, Wrangell, (US 423091); River Road above Hyder, June 18, 1924, Kirk Whited 1222, (MBG 925546).

ArizonA: Mt. Lemmon, July 28, 1926, Peebles, Harrison \& Kearney 2517, (MBG 965354).

Arkansas: Five miles East of Mt. Ida on Highway 270, Garland Co., just off road in sandy soil, April 27. 1935. Maude C. Lodewyks 165. (MBG 1095075); Savoy, Washington Co., April 20, 1927, D. Demaree 3017, (MBG 960742).

British Columbia: Glacier at the "Loup," August, 1897, Mr. and Mrs. Cornelius Van Brunt, (type of $V$. brachypetala Rydb.), (NY); Victoria, Vancouver Island, May 31, 1893, John Macoun 5998, (paratype of $V$. brachypetala Rydb.). (NY); Deer Park, Columbia River, June 6, 1890, John Macoun (paratype of $V$. brachypetala Rydb.), (NY); Prince George, June 30, 1935, O. J. Murie 1291, (MBG 1105542).

California: Tamalpais, April 13, 1913, E. O. Wootton, (US 663951); Hems Station. Amador Co., $5000 \mathrm{ft} ., 1895$, Geo. Hansen 1076. (MBG 147029).

Colorado: S. E. of Ouray, chaparral covered hills, 2300-2600 meters, Sept. 7. 1901, M. L. Underwood \& A. D. Selby 79, (This was the only specimen seen from Colorado, the leaves were long and narrow, shortly but distinctly petioled), (NY).

Connecticut: Storrs, May 8, 1907, (inflorescence sessile), (MBG 792128).

Delaware: Tidestrom 7913, (MBG 806800).

District of Columbia: (MBG 147054).

Georgia: De Kalle Co., Steene Mt., May 20, 1897, H. Eggert (MBG 147012); Yellow River, Gneime Co., July 27, 1897, H. Eggert, (MBG 147013); Rome, Dr. Ravenel, (MBG 147065).

Illinors: Bellville, July 3, 1891, E. Douglas, (MBG 147005); Richland Co., May 16, 1922, R. Ridgway 1595, (MBG 916691).

Indiana: Osborne, August 28, 1909, Greenman 2839, (MBG 738629).

Iowa: Bentonsport, Rich Woods, June 1920, E. W. Graves 1796. (MBG 975281); Decatur Co., Rich woods, May 23. 1898, J. T. Fitzpatrick. (MBG 147018); Iowa Lake, Emmett Co., June 1899, R. I. Cratty, (MBG 147003).

Kansas: Cherokee Co., Rich woods, 1896, A. S. Hitchcock 835, (MBG 147033).

Kentucky: Natural Bridge, May 26, 1923, F. F. McFarland 69, (MBG 904091); Pine Mt., Bell Co., Sept. 1893. T. H. Kearney Jr. 348, (MBG 147045); Hopkinsville, May 26, 1920. Palmer 17655, (MBG 861596).

MaINe: Orono. Penobscot Co. \& River, Rocky, open woods, July 26, 1895 , Fernald 342 (MBG 147017); Washington, Knox Co., Moist, rich woods, August 24, 1929. Steyermark 882, (MBG 1026026).

MAssachusetts: Concord, May 30,1896, Greenman 2292, (this resembles very much the type of $V$. ausiralis Rydb., supposedly a strictly southern form), (MBC 147074); Mongut, June 19,1888, E. L. Sturvetantii (MBG 147074); Tynsboro, May 26, 1929; Fred'k S. Beattie, (BY).

Michigan: Douglas Lake, Emmet Co., in aspens. F. D. \& M. T. Gates 10263, (MBG 823299); Cheboygan Co., F. C. \& M. T. Gates 10514; (MBG 823897).

Minnesota: E. Shore Lake Josephine, Hubbard Co., July 16, 1933, J. B. Moyle 862, (MBG 1078018); Mankato River, June, 1818, C. C. Parry, (MBG 147057). 
Missıssipp1: Tchula, April 18, 1927, R. E. Woodson \& E. S. Anderson 1529. (MBG 934634).

Missourı: Eureka, May 18, 1901; J. H. Kellogg, (MBG 910145); Creve Coeur Lake, June 26, 1905, A. G. Johnson, (MBG 147044); Dodson, Jackson Co., Rich Woods, May 26, 1917. R. Hoffman (MBG 857806); St. Louis, July 26, 1890; Hitchcock, (MBG 147032).

New Brunswick: Lily Lake, July 22, 1877, J. Fowler, (MBG 147020).

New Hampshire: Mt. Kearsage, White Mts., North Conway, June 10, 1874, Morong. (MBG 147051); Crawford Notch, July 3, 1898, Greenman 1128, (MBG 722195).

New Jersey: Summit Co., R. Perry 32. (MBG 147059).

New Mexico: Alamo National Forest, Haynes Canyon, in poplar thickets, August 10, 1911, Bronson Barlow, (MBG 146923).

New York: Ithaca, May 31, 1891, H. S. Schrenk, (MBG 147080).

North Carolina: Biltmore, May 29, 1897. (MBG 146991); Chapel Hill, dry woods, May 11, 1928, Edgar Anderson. (MBG 942593).

North Dakota: Fargo, rich soil, woods, July 21, 1912, H. F. Bergman, (MBG 743403).

Nova Scotia: New Germany, June, 1891, Dr. Chas. A. Hamilton, (NY).

Oніо: Greenman 1258, (MBG 722193).

Okцahoma: Page, Rich woods, hillside, July 27, 1917, Palmer 12646, (MBG 828965).

Oregon: Multnomah Falls, May 30, 1899, T. H. Kearney Jr. \& Coville 263, (US 373356): Corvallis, May 24. 1922, C. C. Epling 5096, (MBG 965206); Sykes Creek, Jackson Co.,May 26, 1892, E. W. Hammond 380, (MBG 86815).

Pennsylvania: Mt. Alto, June 6, 1908, Jos. Illick, (MBG 147038); Mt. Ville, May 1891, Eby, (MBG 147008).

RHode IsLand: Greenman 1835, (MBG 722435).

South Carolina: Anderson, July 15, 1919, Rev. John Davis 8411, (MBG 855304).

South Dakota: Lead, Hillside, June 24, 1928, H. E. Lee (MBG 1078686); L. Oakwood, Griffths, Thos. A. Williams, (MBG 147028).

Tennessee: Knoxville, May 18, 1898, Albert Ruth 151, (MBG 147070).

Texas: Davis Mts., Jeff Davis Co., Oct. 4, 1926. E. J. Palmer 31960, (this is an unusually large specimen, having pedicels up to $3 \mathrm{~mm}$. long, seeds $4 \mathrm{~mm}$. broad), (MBG 961690).

Vera Cruz: Canton Cordoba, Cerro de Choraman, im nassigen Bergwaldern, May 12, 1907, Caec. et Ed Seler. 5174, (US 1206028).

Vermont: Fairlee, Palisades, July 16, 1927, M. Mathias 145, (MBG 940334); Brandon, rich woods, June 5, 1922, D. L. Ditton, (MBG 915059); Peacham. August 6, 1885, F. Blanchard, (MBG 750369).

Virginia: Little Neck, Princess Anne Co., dry mixed woods, August 8 and 9 , 1934, Fernald \& Long 3859, (type of S. racemosa var. cylindrata Fernald), (GH); Luray, Stony Man Mt. Blue Ridge, 3500 ft., August 31, 1901, Mr. \& Mrs. E. S. Steele, (MBG 147073).

Washington: Seattle, May 21, 1891, C. V. Piper 198, (paratype of V. brachypetala Rydb.), (NY); Olympic Mts. Clallam, June, 1900, A. D. E. Elmer 2500, (MBG 146933).

West Virginia: Buckhorn, Upshur Co., May 17, 1895, W. M. Pollock, (MBG 147060); Davenport, Tyler Co., June 21, 1930, E. E. Berkeley 764, (MBG 994193).

Wisconsin: Ephraim, June 5, 1907, J. M. Greenman 3168, (MBG 740328). 


\section{1a. Smilacina racemosa (L.) Desf. var. amplexicaulis (Nutt.) S. Wats. in King, Geol. Expl. 40th Par. 5:345. 1871}

Differs from the species in the acute or very short-acuminate leaves which are usually more or less clasping by the sessile base, or by a broadly-winged, short petiole, and are usually broadest toward the base.

The variety ranges from British Columbia and Alberta south through Colorado to Western Texas and California. It appears to be found exclusive of the species in Utah and Nevada and probably also in Idaho and Colorado. Only one specimen from Colorado which seems to be the typical form of the species has been cited. Therefore the origin of the variety was probably in the Great Basin and surrounding mountains. Like the species, it is wanting in treeless regions, and in the Great Basin is rarely found under 6,000 ft. elevation. (Fig. 1.)

This form in American literature has generally been regarded as a distinct species. Dr. Sereno Watson in his "Revision of the North American Liliaceae" so accepted it, although he had previously published it as a variety. Index Kewensis does not list it, however.

Professor Harold St. John, (25) p. 96, in 1929, investigating the genus, reduced it to synonymy. His acquaintance with the group, however, was primarily with specimens of the Pacific Northwest, where intergradation is most marked.

Smilacina amplexicaulis Nutt. ex Baker, Journ. Acad. Philad. 7:58. 1834.

Unifolium amplexicaule Greene, Bull. Torr. Bot. Cllub, 15:287. 1888. Based on S. amplexicaulis Nutt.

Vagnera amplexicaulis Greene, Man. Bot. Bay Region. 316. 1894. Based on S. amplexicaulis Nutt.

Smilacina lalifolia Nutt. ex Baker, Journ. Linn. Soc. 15:570. 1875.

Vagnera pallescens Greene, Proc. Acad. Sci. Philad. 1895:551. 1896.

(Not $V$. pallescens of Heller and many herbaria.)

Smilacina racemosa brachystyla Henderson. Bull. Torr. Club. 27:357. 1900.

Vagnera amplexicaulis brachystula Heller, Cat. N. A. Plants, Ed. 2, 4. 1900. Based on $S$. racemosa brachystyla Henderson.

Smilacina amplexicaulis Nutt. var. glabra Macbr. Contr. Gray Herb. II $41: 18.1898$.

Vagnera amplexicaulis glabra Abrams, Illust. Fl. Pacif. States. I:453. 1923. Based on S. a. Nutt. var. glabra Macbr.

Smilacina racemosa (L.) Desf. var. glabra St. John, Res. Stud. State College of Wash. 1 :97. 1929. Based on S. a. Nutt. var. glabra Macbr.

Following is the basis for elimination of each of the above synonyms.

Smilacina latifolia Nutt. A photograph of the type specimen which was examined during this study reveals nothing distinctive in this form from "Rumbia Woods, Rocky Mts." The leaves are broadened toward the base and loosely clasping by a broadly winged petiole. The apex of the leaves tends toward the typical form, being abruptly short-acuminate.

Vagnera pallescens Greene. Greene described this species as differing from " $V$. amplexicaulis" in its smaller size, inclining rather than erect habit, glaucous 
rather than bright green aspect, and its range at "higher than middle elevations of the California Sierra, from at least Fresno Co. northward."

One specimen labeled in Greene's handwriting as $V$. pallescens has been seen. This seems a typical, though smaller than average, form of the var. amplexicaulis. The only distinguishing feature is the rather short panicle-branches, not mentioned by Greene. The habit of the aerial stem varies too much, even among stems from the same rootstock, to have any weight. Neither can degree of glaucousness or pubescence be regarded as significant when the variation through the range of the form is considered.

From the description this form would be taken for MacBride's "var. glabra" published later if it were not that he describes $V$. pallescens as "not glabrous" and the leaves as "stiffly hirtellous beneath."

Smilacina racemosa brachystyla Henderson. Smilacina racemosa and $S$. amplexicaulis have been classically considered as being distinguished, among other things, by the longer style of the latter although in the original description its style is mentioned as being "very short." Henderson proposed this variety to cover those western forms which have the leaf shape of the var. amplexicaulis but short styles.

In a comparative study made of 15 specimens of each form, selected at random, the styles of $S$. racemosa were found to range from .3 to $1 \mathrm{~mm}$. with an average of $.53 \mathrm{~mm}$.; the var. amplexicaulis to range from .4 to $1.2 \mathrm{~mm}$. with an average of $.75 \mathrm{~mm}$. Among the forms of var. amplexicaulis, those with styles less than $.7 \mathrm{~mm}$. were from Idaho, Arizona, and Colorado; with styles more than $.7 \mathrm{~mm}$., from Oregon, Montana, British Columbia, and Utah.

A study made with such a small number of specimens can hardly be regarded as conclusive, especially as such short lengths are difficult to measure accurately; yet the results do indicate that there may be a tendency for styles to average longer in the Western form. The extreme variability of this factor throughout North America, however, makes it impossible to regard it as a basis for another variety.

Smilacina amplexicaulis Nutt. var. glabra Macbr. is based on a wholly glabrous form found at high elevations of the Sierra Nevada from B. C. to California. The leaf type is invariably that of the var. amplexicaulis. The plants are generally smaller and more glaucous than is usual for the variety.

This might merit rank as a "forma" of the variety. However pubescence is very variable, and forms which are glabrous on the lower part of the stcm and lower leaves, or pubescent only in the inflorescence are frequent and widely distributed. Further, the multiplication of names is awkward.

Glabrous specimens of $S$. racemosa are occasionally found in Texas.

\section{Selected Specimens}

Alberta: Rosedale. Wooded Hills, 2200-2500 ft., June 15, 1915, Marion E. Moodie 931. (MBG 800647).

Arizona: Monument Peak, Chiricahua Mts., north slope, in aspen woods, $8500 \mathrm{ft}$., September 27, 1906, J. C. Blumer Pr. 133. (This is labeled "type of S. Blumeri 
Greene," an unpublished name. This is a small form resembling Rydberg's $V$. australis. Some specimens from this locality have a subspicate inflorescence, the flowers growing in umbelliform clusters along the axis.) (US 563499).

California: Jonesville, Butte Co., 2100 meters, June 16, 1931, E. B. Copeland 616, (MBG 1021630); Sancelitos Hills, March 31, 1869; A. Kellogg \& W. G. W. Hartford 996, (MBG 146942); Cisco, Yuba River, 5500 ft., June 17, 1917, A. A. Heller 12706, (glabrous form), (MBG 825288).

Colorado: Norwood Hill, San Miguel Co., Moist north slopes, $7000 \mathrm{ft}$., August 16, 1912, Ernest P. Walker 468, (US 543797); Near Pagosa Peak, S. Colo., August 3. 1899. C. F. Baker 256 (labeled "S. glomerata Greene," an unpublished name. The panicle-branches are very short and compact.) (US 543797); Flagstaff Mt., Boulder, June 25, 1906, F. Daniels 143, (MBG 146931).

IdAHo: Hereford R. S., 7500 ft., June 7, 1928, W. P. Cottam, (BY 3023); Oxford, May 6, 1885, F. E. Leonard 43, (NY); Henry's Lake \& Mt. Chauvet, 10,000 ft., July 7, 1897, Rydb. \& Bessey 3879, (NY); Tamarack, Washington Co., (MBG 146928).

Montana: (Missoula, Woods, May, 1917, J. A. Hughes 1061, (MBG 895666).

Nevada: Mt. City, Mill Creek, in aspens, $7000 \mathrm{ft}$., August 14, 1912, A. Nelson \& J. F. MacBride 2208, (MBG 712043).

New Mexico: Harvey's upper ranch, Pecos R. National Forest, $9600 \mathrm{ft.}$., August 1, 1908, P. C. Standley 4613, (MBG 146967); Gila National Forest, under douglas-fir, $8000 \mathrm{ft}$., (labeled "S. glomerata Greene ined."), (US 583102).

Oregon: Alpine meadows on east side of Crater Lake, July 23, 1935, J. Wm. Thompson 12273. (glabrous form. labeled "topotype of S. racemosa var. glabra (Macbr.) St. John"), (US 1650522); Harbrook Gulch, 4700 ft., July 15, 1897, E. P. Sheldon 8578, (MBG 146962).

Texas: Davis Mts., Jeff Davis Co., moist shaded slope at foot of high, north facing bluff of Mt. Livermore, 2300 meters, June 1, 1928, E. J. Palmer 34293, (NY), (MBG 946427). (Glabrous form).

Utah: Mouth of Logan Canyon, Cache Co., Zundel 169, (NY); Uintah Mountains, 8000 ft., June 27, 1927, W. P. Cottam (BY 2409); Aspen Grove, North Fork, Provo. Sept. 1. 1934, B. F. Harrison, (BY 6521); Zion Canyon, 4500 ft., April 24, 1930, W. P. Cottam, (BY 4774); Arch Canyon, 7000 ft., June 26, 1927, W. P. Cottam, (BY 2434).

Washington: Rumbia Woods, Rocky Mts., (Columbia River?), 6/33 (?) Nuttall, (labeled as "type of S. latifolia Nutt."), (NY) (photograph only); Mt. Paddo, June 14. 1890, W. N. Suksdorf 1006, (MBC 146969); Lake Chelan, Cascade Mts., 1915, A. S. Kammerer 119, (MBG 789950).

WYominc: Woods, rolling plains between Sheridan and Buffalo, Wyoming, 6000 ft., Frank Tweedy 2513 (NY): Hoback Canyon, Teton Co., June 24, 1932, $8000 \mathrm{ft}$., L. Williams \& R. Pierson 713, (MBG 1032739).

Smilacina racemosa (L.) Desf. approaching var. amplexicaulis, (Nutt.) S. Wats.

Arizona: Head of Black River, White Mts., damp places, July 18, 1912, L. N. Goodding 1207. (US 661913).

California: Lassen's Peak, Calif., August, 1896, R. M. Auston, (labeled "S. petiolata Greene," an unpublished name. The leaves are only acute but spreading, on long petioles), (US 294693).

Chinuahua: Sierra Madre, 1899, Barber \& Townsend 8. (US 739667); Las Cuevas, June 30, 1892. C. V. Hartman 544, (US 306037). 


\section{Smilacina stellata (L.) Desf. Ann. Mus. Paris 9:52. 1807.}

Rootstock long, white, $2.4 \mathrm{~mm}$. in diameter; aerial stems numerous, erect, spreading or arcuate, straight or flexuous, $20-70 \mathrm{~cm}$. long, $2-5$ or rarely as much as $7 \mathrm{~mm}$. in diameter, puberulent; leaves 5.15 or rarely $20 \mathrm{~cm}$. long, flat or folded, often distichous, green or pale and glaucous, puberulent, linearlanceolate to lanceolate or falcate, more or less clasping at the base, obtuse to acuminate at apex; inflorescence a simple raceme, sessile or short-peduncled, 1-20 flowered, the rachis often zig-zag; pedicels $2-15 \mathrm{~mm}$. long, erect to spreading; perianth-segments $3.6 \mathrm{~mm}$. long, $1.1 .5 \mathrm{~mm}$. wide, white or greenish; stamens slightly shorter than the perianth-segments; fruit a globose berry about $8-9 \mathrm{~mm}$. in diameter, at first light green with 6 blue longitudinal stripes, later turning dark blue or sometimes red throughout.

Found throughout the United States except in those states lying south of Virginia and Kansas and east of New Mexico; also in Southern Canada from Newfoundland, Prince Edward Island, and New Brunswick to British Columbia; in Alaska, and Chihuahua. (Fig. 2.) Specimens from Norway and Sweden, presumably escaped from cultivation, have also been seen.

This species tends to grow in denser colonies and to frequent more open areas than $S$. racemosa. However the two are sometimes fourd near each other, especially in the western United States.

Perhaps because of its wide distribution, this species is very variable in such characters as habit of the plant and size and shape of the various parts. Many of these forms have been given specific or varietal rank. However the complete intergradation and lack of any definite geographical limitation make it impossible to retain these, with one exception.

Convallaria stellata L. Sp. Pl. 316. 1753.

Tovaria stellata Neck. Elem. 3:190. 1790. (name only). Based on C. stellata L.

Maianthemum stellatum Link, Enum. pl. Hort. Berol. 1:343. 1821. Based on C. stellata $\mathrm{L}$.

Unifolium stellatum Greene, Bull. Torr. Bot. Club 15:287. 1888. Based on C. stellata L.

Vagnera stellata Morong, Mem. Torr. Bot. Club. 5:114. 1894. Based on C. stellata L.

Smilacina sessilifolia Nutt., ex Baker, Journ. Linn. Soc. 14:566. 1875.

Tovaria sessilifolia Baker, I. c., based on S. sessilifolia of Nuttall's Mss.

Unifolium sessilifolium Greene Bull. Torr. Bot. Club 15:287. 1888. Based on T. sessilifolia Baker.

Vagnera sessilifolia Greene, Man. Bot. Bay Region 316. 1894. Based on T. sessilifolia Baker.

Smilacina siellata sessilifolia Henderson. Bull. Torr. Club 27:358. 1900. Based on T. sessilifolia Baker.

Unifolium liliaceum Greene, Pittonia 1:280. 1889.

Vagnera liliacea Rydb. Mem. N. Y. Bot. Gard. 1:101. 1900. Based on U. liliaceum Greene.

Vagnera leptopetala Rydb. Bull. Torr. Bot. Club 28:268. 1902.

Vagnera valida Greene, ex Baker, West. Amer. Pl. 1:19. 1902. (Name only).

Vagnera pallescens of most herbaria and Heller's collection No. 8641 of June 28, 1907. from the "Truckee Pass east of Reno. Nevada." Not $V$. pallescens Greene. 
The basis for elimination of each synonym follows.

Tovaria sessilifolia Baker. This name has been much misunderstood and variously applied, largely because of the great variation and intergradation among western forms of $S$. stellata. As originally given by Baker, the description includes all western forms with flexuous stem and rachis and pedicels more than 3 lines (about $7 \mathrm{~mm}$.) long. This includes a multitude of forms, and is not in itself exclusive. Specimens are often found east of the Mississippi with flexuous stems or rachis and rarely with pedicels as much as $9 \mathrm{~mm}$. long, while in the West, flexuous stems with short pedicels, or long pedicels with straight stem and rachis are common.

In the East, $S$. stellata usually grows in dense colonies in rather open places. There the aerial stems are erect and usually rather short and stout, glaucous, and the leaves are ascending, rather narrow and often folded, and scattered around the stem. The pedicels are short and stout, and the rachis straight.

In the western area it grows in both open and shaded places. In its most extreme form, the shade-loving plant has, as would be expected, a weak, slender, flexuous, spreading stem; broad, flat, thin, distichous leaves which are scarcely at all glaucous; and an open, few-flowered inflorescence with long, slender pedicels and zig-zag rachis. The rootstocks are more slender, and the individual plants tend to be more scattered.

This most extreme shade form is common in the Northwest Coastal region, from British Columbia to Southern Alberta, Wyoming, and Northern California. (This is the same area in which intergradation is most evident between $S$. racemosa and the var. amplexicaulis.)

Every conceivable intergrade between this shade-loving plant and the plant of more open places is found, in these states and many others. From the Southern Rocky Mountains and Southern California are found plants which retain the long pedicels, but tend to be more robust, with stout, though often arcuate, straighter stems, straight rachis, and longer leaves. Arizona and New Mexico specimens are found which are scarcely distinguishable from the Northwest coast form except for the narrower, long-acuminate leaves. Specimens are found in every Western state which are not distinguishable from the Eastern form, along with every possible intergrade.

Index Kewensis gives this species recognition.

Unifolium liliaceum Greene. This name was applied to a rather robust form found in the mountains of southern California (and elsewhere) with erect, straight stem; scattered, bright green, "falcate" leaves, and long, ascending pedicels. Similar specimens are common which have varying degrees of glaucousness; these, except for rather longer pedicels, are not distinguishable from robust specimens of the more typical eastern form. Other specimens are common which differ from Greene's description only in having an arcuate stem and lanceolate, rather than falcate, leaves.

Vagnera leptopetala Rydb. was based on a form found most commonly in the mountains of Wyoming, Colorado, and New Mexico. It is characterized 
by small size of all the parts, with narrow perianth segments; short, weak, arcuate stem; and narrow, flat, distichous leaves. Rydberg describes it as being "pale," but forms otherwise similar but of a bright green color are common in the same area. Except for the arcuate stem and distichous leaves, it is not distinguishable from small specimens of more typical $S$. stellata, and intergrading material is abundant.

Vagnera valida Greene. Specimens bearing this name are occasionally found in herbaria; one has been seen which was also labeled as the type of "Smilacina Greenei Gates ined." This name seems to have never been published. The specimens seen have all been robust, bright green forms with distichous, acuminate leaves. Some have the lower flowers in the raceme abortive. Most of them were collected at "King's Canyon, Ormsby Co., Nevada."

Vagnera pallescens of most herbaria and Heller's collection. This is an extremely vigorous form. A typical specimen has a straight, erect stem $70 \mathrm{~cm}$. high and $7 \mathrm{~mm}$. in thickness with scattered, slightly folded leaves to $21 \mathrm{~cm}$. long, glaucous green and acuminate. The flowers are large and numerous, on long (to $13 \mathrm{~mm}$.) stout, spreading pedicels, from a straight rachis. Many of the specimens show pairing of one or more pedicels, as in $S$. daburica of Eastern Asia.

These plants are among the largest seen, and except for many intergrading forms, might rank as a variety. This was probably the plant Heller had in mind when he listed $V$. pallescens in his Catalog of Plants of North America. He may have confused the name with one of Greene's many unpublished "species," most likely Vagnera valida.

\section{Selected Specimens}

Alaska: Upper Matanuska Valley, Common in drier woods, August, 1913, Ralph W. Chaney 92, (MBG 741699).

Alberta: Wood Buffalo Park. Mackenzie Basin, east shore of Lake Mamawi, $58^{\circ} 35^{\prime}$ N., $111^{\circ} 22^{\prime}$ W., granite hill, August 8, 1930. Hugh M. Raup 2016, (US 1678408).

California: Coldwater Canyon, San Antonio Mts., San Bernardino Co., July 12. 1902, Leroy Abrams 2708, (very large), (NY); McAdams (?) Greek, Siskiyou Co., wet meadow, May 15, 1910, Geo. D. Butler 1343, (labeled " $V$. lileacea Greene, from original station." stems $80 \mathrm{~cm}$. long, leaves to $3 \times 13 \mathrm{~cm}$., long-acuminate, pedicels to $11 \mathrm{~cm}$. long, rather slender, plant glaucous, (US 669312).

Chinuahua: Near Colonia Garcia in the Sierra Madres, $7500 \mathrm{ft}$. June 16, 1899. C. H. Townsend \& C. M. Barber 35. (US 383159).

Colorado: Near 4th of July Mine, July 29, 1906, Frances Ramaley \& W. W. Robbins 2436, (RM 56940); Chick Creek, 9500 ft.. June 27, 1898, Baker, Earle \& Tracy 147. (NY), Pagosa Peak, August 5, 1899. Baker 257, (NY); Dark Canyon. Pike's Peak, $9700 \mathrm{ft}$., July 22, 1901, Clements 242, (NY); Headwaters of Sangre de Cristo Creek, $9000 \mathrm{ft}$., June 22, 1900. Rydberg \& Vreeland 6441, (type of V. leptopelala $\mathrm{Rydb}$.), (NY).

District of Columbia: Margin of Island, Washington, D. C., May 12, 1918, E. L. Wherry, (this has bright green leaves and erect, curved pedicels up to $7 \mathrm{~mm}$. long), (US 983792); "Difficult Run of River," Washington, D. C.. May 7, 1874 (in flower) and July 5, 1879 (fruiting), Lester F. Ward, (US 134742); along Potomac above Washington, D. C., May 11, 1916, Paul G. Russell, pedicels to $9 \mathrm{~mm}$. long). 
IdaHo: Shoshone, May 27, 1899. D. Alton Saunders 3235, (a large form, labeled S. Greenei), (MBG 146973).

Michigan: St. Joseph, May 23, 1913, J. A. Nieuwland 11070, (this has pedicels in pairs, one in 3 's on lower part of raceme). (MBG 711708).

Minnesota: U. S. Govt. Prop. Sec. 20, Minnesota Point, Duluth, in large colonies, under shrubs, in gravel and sand, August 31, 1936. Olga Lakela 1803, ("Large"), (FM 901512); Olga Lakela 1802, ("Small"). (FM 901528), "The large form grows in distinct colonies from the smaller."

Nevada: King's Canyon, Ormsby Co., 1700-2000 meters, June 10, 1902, C. F. Baker 1038, (labeled "Type of S. Greenei n. sp. Gates, Aug. 1915" on MBG specimen, also "Vagnera valida Greene n. sp., det. by Greene," tall, stout, leaves large, lanceolate, dark green and glaucous, lower flowers abortive, one born below upper leaf, upper flowers well developed on rather short pedicels, rachis straight), (MBG 146972), (US) (RM43941); Same as above but smaller, with normal inflorescence (RM 157613); Truckee Pass, E. of Reno, June 28, 1907, Heller 8641, (labeled " $V$. pallescens Greene"), (NY, also in most other large herbaria): "N. W. Nevada," July, 1867. W. W. Bailey 1169, (US 36053). 60100).

SWEDEN: Upsala, 1869, R. Olberg. (one specimen has forked inflorescence), (US

Utah: Provo River, $4550 \mathrm{ft}$., May 28, 1933, B. F. Harrison (BY 6166); Clear Creek, $5500 \mathrm{ft}$., June 7, 1928, W. P. Cottam, (BY 2999); Head of Moon Lake. Ashley Forest, $8100 \mathrm{ft}$., June 7. 1928, B. F. Harrison, (BY 7644). 7914).

WYoming: Lonetree, 7200 ft., June 20, 1934, B. F. Harriscn \& E. Larsen, (BY

\section{2a. Smilacina stellata (L.) Desf. var. crassa Victotin, Contrib.}

\section{Lab. Bot. Univ. Montreal 14:16. 1922}

Differs from the typical eastern form in the fleshy, relatively broad leaves; the thick but short stem; and the maritime habitat. The leaves are usually numerous and crowded, the stem reddish, and the whole plant extremely glaucous when young, glabrescent in age, when the veins appear unusually prominent. The type specimen has ovate, rounded leaves; others examined are narrower and acute.

This variety seems to be confined to the region of the Gulf of St. Lawrence, and is largely an island form, though it is occasionally found in the interior of Quebec. Victorin states that it is found in marshy areas and is the halophytic form of the species (30, pp. 16-17.) (Fig. 2.)

Further study and collections are needed of this interesting but little-known form. It seems to be quite distinct both morphologically and ecologically, though a few specimens have been seen which appear to be intermediate.

\section{Specimens Examined}

New Brunswick: Grand Menace, J. L. Rothrock, (FM).

Quebec: Archipel de Mingan. Ile Nue, sur un îlôt, bird sanctuary. July 9, 1926, Victorin \& Rolland 24249, (type), (MV, UM); Alright Island, Magdalen Islands, sand ridge bordering the strand at the narrows, August 21, 1912, Fernald, Long \& St. John 7194 (MV); Natashquan, sur les dunes de l'embouchure, July 28. 1929. Victorin \& Germain 28191, (MV, US 1522312); Natashquan, sur les dunes du côte sud d l'estuaire. July 21, 1924, Victorin \& Rolland 18480, (UM); Archipel de Mingan: Ile a Bouleau, sur les rivages, August 4, 1924. Victorin \& Rolland 18532, (UM); Iles de 
la Madelaine, Ile Brion, sur les dunes, communes, August 3, 1919, Victorin \& Rolland 9849, (UM); Carleton. Ca. de Bonaventure, La Gaspesie, sur les graviers secs du barachois, August 12. 1930. Victorin \& Rolland 33561, (UM); lles de la Madelaine, Havre aux Maisons, July 24, 1919, Victorin \& Rolland, (UM).

\section{Smilacin.a trifolia (L.) Desf. Ann. Mus. Paris 9:52. 1807}

Rootstocks very long and slender, scaly; aerial stems low, $5.30 \mathrm{~cm}$. long, glabrous, the sterile shoots with usually 2 leaves and the fertile ones 3-5. Leaves lanceolate or oblanceolate to elliptic, acuminate, acute, or rounded at apex and tapering to a sheathing base, $3.13 \mathrm{~cm}$. long, $1.4 \mathrm{~cm}$. broad; inflorescence a simple raceme, 2-12 flowered, pedunculate; pedicels spreading or ascending, $2-10 \mathrm{~mm}$. long; berry $5.6 \mathrm{~mm}$. in diameter, dark red, turning blue in drying.

This species has a rather spotty distribution in the colder temperate regions of North America and Siberia. It is found in a broad belt from Connecticut to Minnesota, Newfoundland, Labrador, and Manitoba; appears occasionally in the Mackenzie Basin, Alberta, and Montana; and in Siberia is found in the vicinity of the Zea River. It is found only in cold, acid soil in Sphagnum bogs. (Fig. 2.)

Convallaria trifolia L. Sp. Pl. 316. 1753.

Unifolium trifolium Greene, Bull. Torr. Bot. Club, 15:287. 1888. Based on C. trifolia L.

Vagnera trifolia Morong, Mem. Torr. Bot. Club, 5:114. 1894. Based on C. trifolia L. Smilacina trifoliata Desf., according to Barclay, New Cycl. Amer. Hort. 1672. 1906. Vagnera pumila Standl. Smithsonian Misc. Coll. 56, No. 33:1. 1912.

Vagnera pumila was described from a collection of depauperate material in Alberta. It was described as distinguishable by the dwarf size, short leaves much exceeded by the inflorescence, less spreading pedicels, and short, thick style. These characters can all be matched in depauperate specimens collected in the eastern portion of the range (New York, Wisconsin, etc.). The style on the Standley collection is shorter than usual for the species; however this character may vary considerably, even on individual flowers on the same plant. Other specimens seen from Alberta are like the typical forms.

\section{Selected Specimens}

Alberta: Slave Lake District, Damp Forest, N. Atauwau River (Salteau), June 6. 1929, A. H. Brinkham 4165, (NY); Prairie Creek, Western Alberta, July 3, 1911 , J. H. Riley 100, (type of $V$. pumila Standl.), US 622636); Wood Buffalo Park, Mackenzie Basin. Moose (Eight) Lake District, about $59^{\circ} 36^{\prime} \mathrm{N}, 113^{\circ} 7^{\prime}$ W., Muskeg E. of ranger station, August 12, 1929, Hugh M. Raup 2019, (NY).

Manitoba: 1898, E. S. Thompson. (MBG 1147243).

Michigan: Reese's herb in Thuja bog in openings, June-August, 1917, F. C. \& M.

T. Gates 10491, (MBG 829791).

Montana: G. C. Swallow. (MBG 147076). (This has two leaves, one is $5 \mathrm{~cm}$. broad, amplexicaul, exceeding raceme, petioles 1-2.5 mm. long, plant young).

Newfoundland: Vicinity of Balena, Hermitage Bay, Bog, July 7, 1903, Wm. Palmer 1405, (labeled $V$. pumila), (US 492241); Dark Harbor, bogs, May 7, 1896. A. C. Waghorne 40, (MBG 147241).

NEw YorK: "Fiddlers' Green," Pecksport, in deep sphagnum of the "green," June 9 , 
1916, Wm. R. Maxon 6918, (labeled $V$. pumila), (US 789487).

Prince Edward Island: July 30, 1901, J. R. Churchill, (MBG 739868).

Siberia: Zejskaja Pristań, am Zeaflusse, auf nassen Bergwiesen, June, 1899, I. Dörfler 271, (labeled $V$. pumila), (US 1310274).

Vermont: Mt. Mansfield, July 2, 1897, J. M. Greenman 1255, (MBG 722196).

Wisconsin: Brown Co., June 2, 1886, J. H. Scheutte, (labeled V. pumila), (US 752322).

\section{Excluded Species}

Smilacina alpina, Royle, Illustr. Bot. Himal. $380=$ Clintonia.

Smilacina bifolia Schult. f. Syst. vii. $307=$ Maianthemum.

Smilacina borealis Ker-Gawl. in Bot. Mag. 55. 1155, $1403=$ Clintonia.

Smilacina canadensis Pursh, Fl. Am. Sept. i. $233=$ Maianthemum.

Smilacina cordifolia Becker, Fl. Frankf. i. $136=$ Maianthemum.

Smilacina dilatata Nutt. ex Baker, Journ. Linn. Soc. xiv. 563. 1875. = Maianthemum.

Smilacina Eschscholtziana Andrz. \& Bess. ex Baker, Journ. Linn. Soc. xiv. 564. 1875. = Maianthemum.

Smilacina streptopoides Ledeb. Fl. Ross. iv. $128=$ Streptopus.

Smilacina umbellata Desf. Ann. Mus. Par. 9:53. 1807.= Clintonia.

Smilacina uniflora Menz. ex Hook. Fl. Bor. Am. 2:175. t. 190. = Clintonia.

\section{Summary}

This paper is a taxonomic study of Smilacina of Desfontaines growing naturally in temperate North America. The following species and varieties are retained:

Smilacina racemosa (L.) Desf.

Smilacina racemosa (L.) Desf. var. amplexicaulis (Nutt.) S. Wats.

Smilacina stellata (L.) Desf.

Smilacina stellata (L.) Desf. var. crassa Victorin.

Smilacina trifolia (L.) Desf.

The species retained in the present work are natural and readily distinguishable, the same as those proposed by Linnaeus, later retained by Sereno Watson in his study of the Liliaceae, and with one exception, that of $S$. sessilifolia, which is united with $S$. stellata in this study, accepted by Index Kewensis. The varieties have fairly definite geographic limitations and the majority of specimens can be immediately placed, although intermediate forms occur.

\section{ACKNOWLEDGMENTS}

Appreciation is here expressed to all individuals and institutions who have contributed in any way to the preparation of this paper. I wish especially to thank Professor B. F. Harrison of Brigham Young University at Provo, Utah for his unfailing encouragement and cooperation, and for his criticism of the manuscript.

I am also indebted to the Missouri Botanical Garden and the New York Botanical Garden for transcripts of unavailable literature, and to the following persons and institutions for the loan of herbarium material: 
Field Museum of Natural History, Chicago, Illinois.

Professor A. O. Garrett, 791 Ninth Ave., Salt Lake City, Utah.

Gray Herbarium of Harvard University, Cambridge, Mass.

Missouri Botanical Garden, St. Louis, Missouri.

University of Montreal, Montreal, Quebec.

Brother Marie-Victorin, Montreal, Quebec.

The New York Botanical Garden, New York City, N. Y.

Pomona College, Claremont, California.

Smithsonian Institution, United States National Museum, Washington, D. C.

Utah State Agricultural College, Logan, Utah.

The University of Wyoming, Laramie, Wyoming.

I also wish to thank the following individuals for furnishing special advice or information: C. C. Gregg of the Field Museum of Natural History; A. O. Garrett; M. L. Fernald of the Gray Herbarium; Professor Harold St. John of the University of Hawaii, Honolulu, Hawaii; J. M. Greenman of the Missouri Botanical Garden; Brother Marie-Victorin; G. L. Wittrock of the New York Botanical Garden; Ellsworth P. Killip of the United States National Museum; and Dr. Paul C. Standley of the Field Museum.

\section{REFERENCES}

1. Baker, J. G. 1834- “Smilacina amplexicaulis." Journ. Acad. Nat. Sci. Phila. 7: part 1. 58.

2. Baker, J. G. 1875-“'On Asparagaceae.” Journ. Linn. Soc. 14:556.

3. Barclay, F. W. (revised by F. Tracy Hubbard). 1922-Bailey's The Standard Cyclopedia of Horticulture. The Macmillan Co. New York. pp. 3172-3173.

4. Britton, N. L. ANd A. Brown 1913-An Illustrated Flora of the Northern States and Canada. Second Edition. 1 :515-516. Charles Scribner's Sons, New York.

5. Coulter. John M. and Aven Nelson 1909-New Manual of Botany of the Central Rocky Mountains. 120. American Book Co. Cincinnati, Chicago.

6. Desfontaines, R. L. 1807-Smilacina. Ann. Mus. Hist. Nat. Paris. 9:51-54.

7. Engler, A. and K. Prantl-Die Natürlichen Pflanzenfamilien. 2, 5: p. 79.

8. Fernald, M. L. 1938-Noteworthy Plants of Southeastern Virginia. Rhodora, $40: 404-407$. PI. 512, 513. Oct.

9. Garrett, A. O. 1936 Spring Flora of the Wasatch Region. 34. Stevens and Wallis, Inc. Salt Lake City.

10. Greene, E. L. 1889-New or Noteworthy Species, IV, Pittonia, 1:280, 281.

11. Greene, E. L. 1895-Vagnera pallescens. Proc. Acad. Nat. Sci. Phila. 551.

12. Heller, A. A. 1900-Catalogue of North American Plants North of Mexico. Second Edition. 52.

13. Henderson, L. F. 1900-New Plants From the Northwest. Bull. Torr. Bot. Club 27:356-358.

14. Hutchinson, J. 1934-The Families of Flowering Plants. II Monocotyledons. 94-95. MacMillan and Co. Limited. St. Martin's St., London.

15. INDEX KewENsis. 924-925. 1895-Also citations to "Smilacina" in 1st, 2nd, 5th, and 8 th supplements.

16. Jepson, W. L. 1925-A Manual of the Flowering Plants of California. 249. Associated Students Store, University of California. Berkeley, Calif.

17. Linnaeus, C. 1753-Species Plantarum 315-316.

18. MCBride, J. F. 1918-Smilacina amplexicaulis, Nutt., var. glabra. Contr. Gray Herb. II, $41: 18$. 
19. Morong. 1894-Vagnera. Mem. Torr. Bot. Club 5:114.

20. Piper, Charles V. and R. Kent Beattie $x x x x$ Flora of the Northwest Coast. 103-104. The New Era Printing Company. Lancaster, Pa.

21. Robinson, B. L. ANd M. L. Fernald 1908-Gray's New Manual of Botany. 7th Edition. 291. New York, Cincinnati, Chicago. American Book Co.

22. Rydberg, P. A. 1900-Catalogue of the Flora of Montana and the Yellowstone National Park. Mem. N. Y. Bot. Garden. 1:101.

23. RYdrerg, P. A. 1922-Flora of the Rocky Mountains and Adjacent Plains. 2nd Edition. 166-167. Published by the Author, New York. 1922.

24. Rydberg, P. A. 1901-Studies on the Rocky Mountain Flora. Bull. Torr. Bot. Club. 28:268-269.

25. St. John, Harold-1929-New and Noteworthy Northwestern Plants, Part 3. Research Studies State Coll. Wash. 1:95-97.

26. Sampson, Arthur W. 1919-Plant Succession in Relation to Range Management. U. S. D. A. Bulletin, No. $791: 36-37,39$. Washington, D. C.

27. Small, J. K. 1903-Flora of the Southeastern United States. 270, 1328.

28. Standley, Paul C. 1912-Vagnera pumila. Smithsonian Misc. Coll. 56, No. 33:1.

29. Tidestorm, Ivar. 1925-Flora of Utah and Nevada. Cont. U. S. Nat. Herb. 25:127. Government Printing Office. Washington, D. C.

30. Marie-Victorin. 1929-Les Liliiflores du Quebec. Cont. Lab. Bot. Univ. Montreal. $14: 15-17,39,80-86$.

31. Watson, Sereno. 1871-In King, Geological Exploration of the 40th Parallel. $5: 345$.

32. Wooton, E. O. and Paul C. Standley. 1915-Flora of New Mexico. Cont. U.S. National Herb. 19:139. Government Printing Office, Washington, D. C.

Brigham Young University.

Provo, Utah. 


\section{APPENDIX}

TRANSCRIPTS AND TRANSLATIONS

In Chronoligical Order of Date of Publication. 
1. Linnaeus, C. 1753--Species Plantarum 315-316.

Description of species now referred to Smilacina. Translated from the original Latin by Desma H. Galway.

CONVALLARIA

Smilaxes. T. Corolla rotate

racemosa. 5. Convallaria leaves sessile, raceme terminal, compound.

C. raceme compound hoy lugdb. 26

C. leaves altermate, raceme terninal. Hort. Cliff. 125 Gron. Virg. 38

Polygonatum racemosum Corn. Canad. 36 t. 37

P. ramosum and racemosum spicatum Morris Hist. 3. p. 357 s. 13. t. 4. 卢. 2.

P. racemosum americanum, white hellebore with large leaves. Pluk. alm. 301. t. 311 . ‥ 2 .

Habitat in Virginia, Canada. Perennial.

stellata. 6. Convallaria with many amplexicaul leaves, terminal simple raceme. Polygonatum of Virginia, erect, spiked, flowers star-like. Morris hist. 3. p. 536. s. 13. t. 左. f. 7 . Polygonatum of Canada, spiked, fertile. Corn. Canad. 33. t. 33 .

Habitat in Canada. Perennial.

trifolia. 7. Convallaria with three amplexicaul leaves, terminal simple raceme.

Convallaria with racemose flowers, leaves ovate-oblong, cauline. Gmel. sibir. I. p. 36 . t. 4 .

Phalangium with Veratrum-like leaves. Amm. ruth. 137.

Habitat in Siberian Woodlands. Perennial 
2. Desfontaines, R. I. 1807--Annales du Museum

D'Histoire Naturelle a Paris. 9:51-54.

Description of the genus Smilacina and the species $\underline{\text { S. racemosa, }}$ S. stellata, $\underline{\text { S. trifolia, }}$ and $\underline{S}$. ciliata.

Translated from the original French by Desma H. Galway and Irene O. Spears.

\section{SWILACINA (Smilacina)}

Calyx none. Corolla with six distinct segments, opened into a star. Six separate stamens, attached at the base of the segments. One style. One superior ovary. Berry spherical, three-lobed. Stem leafy. Flowers terminal.

\section{Smilacina racemosa}

S. leaves sessile, ovate, nerved, (inflorescence) terminal, racemose-paniculate.--Convallaria racemosa Lin. Spec. $452=$ Polygonatum racemosum. Cornut. Canad. 36 Icon = Smilax spicata polygonati folio. Tournef. Inst. 654 .

Root (stock) thick, white, fleshy, jointed. Stem a little flexuous, about one metre tall, simple and sometimes two-forked, pubescent, angular. Leaves large, sessile or almost sessile, oval, terminating in a point, slightly ciliate on the margins, marked with prominent longitudinal nerves. Corolla with the six very deep divisions lanceolate, acute, open and star-like. Six separate stamens. One style. Berry round, with many scattered red spots at the age of maturity.

This species is cultivated in the gardens of Europe. It is remarkable for the beauty of its foliabe and for its spotted berries. It grows naturally in Virginia and Canada. 


\section{Smilacina stellata (star Smilacina)}

S. Ieaves amplexicaul, ovate-elliptic; raceme simple, terminal.--Convallaria stellata Lin. Spec. 452. - Polygonatum canadense spicatum, sterile et fertile. Cornut. Canad. 34, Icon.= Smilax spicata polygonati folio. Tournef. Inst. 654 .

Stem straight, simple, cylindrical, three to six centimeters high. Leaves alternate, glabrous, arranged in two rows, oval-oblong, a little acute, longitudinally nerved, halfway clasping the stem; up to seven or eight centimeters long and four or five centimeters broad. Flowers disposed in a simple, terminal raceme. Corolla white, divisions very deep, lanceolate. Style triangular. Three stigmas. Berry spherical, at first white veined with purple circular lines. It turns red upon maturity and the lines disappear.

It is originally from Virginia: it is cultivated in the gardens of Europe. It loves shade and flowers in summer. According to Cornuti, it was Jean Robin who first cultivated this pretty plant in France. The same author adds that its berries have a bitter, disagreeable flavor.

\section{Smilacina trifolia (Smilacina with three}

S. leaves oblong-oval; stem pubescent; raceme terminal, lax;-- convallaria trifolia. Iin. Spec. 452 . = Convallaria floribus racemosis; foliis ovatis, oblongis, caulinis. Gmel. Siber. l, p. 36, t. 6 .

Root(stock) creeping, slender, covered with fibers. Stem straight, simple, two decimeters high, bearing two or three alternate, oval-oblong leaves, often terminating in a point, contracted and clasping at base. Five to nine flowers 
disposed in a terminal, drooping raceme. Corolla white, with six very deep divisions. Six stamens. Filaments violet at apex. Berry red, spherical, containing two or three seeds. America.

This plant is found in Siberia and in North

(Translation of Smilacina umbellata description is omitted, as it is correctly referred to clintonia.

\section{Smilacina ciliata (Ciliate Smilacina) Tab. 9}

S. stem simple, arcuate; leaves sessile, ovate, ciliate; panicle terminal, dense.-- Polygonatoides of Canada, smaller flowers.--Vellums of the museum.

Root(stock) fleshy, thick, white, running, jointed. Stem simple, arcuate, three to six centimeters high, naked below, covered the rest of its length with alternate, oval leaves, disposed in two rows, ciliate along the margins, ribbed with longitudinal nerves covered with tiny bristles. Flowers terminal, very small, numerous, crowded, white, disposed in a panicle. Corolla with six very deep divisions which are oval, acute, open. Six stamens, longer than the flower. Anthers thick, short, tetragonal. Ovary superior, pear-shaped, terminated by a short style.

This species, which is very distinct, was formerly cultivated in the Botanical Garden. The engraving of it, which I am publishing, is taken from a sketch by Aubriet, which forms a part of the collection of vellums. 
3. Baker, J. G. 1834.--Journ. Acad. Nat. Sci. Phila. 7: part 1. 58.

Publication of Smilacina amplexicaulis

Translated from the original latin by Desma H. Galway.

\section{BRACHYPETALUM}

Petals very short, appearing star-like, styles very short. Leafy, caulescent herb, flowers paniculate.

\section{Smilacina (B.) *amplexicaulis.}

Leaves cordate-ovate, amplexicaul, sub-acuminate, flowers paniculate, petals slightly shorter than the stamens.

4. Baker, J. G. 1875.--Journ. Linn. Soc. 14:566. "On Asparagaceae."

Publication of Tovaria sessilifolia Baker and Smilacina sessilifolia Nutt.

Translated from the original latin by Desma $\mathrm{H}$. Galway and Irene 0. Spears.

\section{"On Asparagaceae"}

4. T. (Tovaria)SESSIIIFOLIA, Baker. Smilacina sessilifolia Nuttall NSS. Stem 1 to $21 / 3$ feet high, maked below, flexuous and minutely puberulent above. Leaves 9-12, oblong-lanceolate, acuminate, 3-6 inches long, sessile, semi-amplexicaul, green and glabrous above, glaucous and minutely puberulent along the veins below. Veins crowded, unequally distinct, the transverse veins not at all apparent. Raceme lax, 6-20 flowered, sessile or shortpeduncled, 1-2 inches long, 10-12 lines broad when expanded, with flexuous rachis. Pedicels solitary, ascending, 3-6 lines long. Bracts minute, lanceolate. Perianth 2-3 lines long, with lanceolate segments. Stamens short, with minute, oblong anthers, 
the perianth nearly twice as long. Style $\frac{1}{2}$ line long. Berry 3-4 lines broad. Western North America from British Columbia to Califormia and New Mexico.

5. Engler, A. and K. Prant1.--1895.--Die Naturlichen Pflanzenfamilien. 2,5: p. 79.

Section on Smilacina. Translated from the original German by Sanford Bingham and Bertrand F. Harrison.

166. Smilacina Desf. (Tovaria Neck., Polygonastrum Moench, Sigillaria Rafin., Asteranthemum Jocaste, Medora Kunth, Neolexis Salisb.)

Perianth-segments 6, spreading. Anthers eggshaped, dehiscing inwardly; cells of the ovary with 2 seeds. Berries with round-oval (bullet-shaped) seeds; the embryo a little shorter or half as long as the endosperm. Stems leafy throughout, ending in a small cluster (raceme) of flowers or a number of small clusters (panicle).

Approximately 20 species from the Himalayas through Eastern Siberia and Mongolia to North and Central America; most widely spread is Smilacina trifolia Desf. from eastern Siberia through subarctic America to Pennsylvania, mostly with 3 long, stem-clasping leaves with a loose cluster of flowers and red berries the size of a pea. Sm. stellata Desf. is often cultivated, with the stem 3-6 dm. high, linear or lanceolate se $s$ sile leaves, 10-20 clustered flowers and dark red berries; native to Northwestern and Eastern America, escaped from cultivation near Christiania, Norway. Sm. racemosa Desf. found commonly in botanical gardens, stem 6-9 dm. long with linear or lanceolate leaves and compact blooming panicle; the berries are pea-size and bluish red; from Western North America through New Mexico to Missouri and Virginia. Besides the se there are 5 species in the Himalayas, 1 in eastern Siberia, $I$ in Japan, 1 in wetern North America, and 7 in the mountains of Mexico and Guatemala. 
6. Marie-Victorin. 1929--Les Liliiflores du Quebec. Cont. Lab. Bot. Univ. Montreal. 14: 15-17, 39, 80-86.

Publication of Smilacina racemosa (L.) Desf. forma foliosa Victorin, Smilacina stellata (L.) Desf. var. crassa Victorin, and other descriptive notes on the genus Smilacina.

Translated from the original French by Desma H. Galway and Irene 0. Spears.

\section{Genus SMILACINA}

a) Smilacina racemosa

The stem of this species is always described as bearing a pedunculate panicle, and the examination of copious material indicates that this is generally the case. However it seems to have a marked tendency towards a form with sessile inflorescence, which I designate as follows:

\section{SMILACINA RACEMOSA (L.) Desf. f. foliosa n. f.}

Lowermost panicle branch in the axil of the uppermost leaf. (fig. I)

$U$ UEBEC: Environs of the city of quebec; August, 1922; Victorin 16009; type in the Victorin Herbarium.

I would also cite, outside of quebec, the following specimen: Dry pine and oak woods on steep slopes along Lahave River, Bridgewater, Lunenberg County, Nova 3cotia; Aug. 16, 1921; Fernald \& Long 23650 .

\section{b) Smilacina stellata}

This species, as it presents itself in the interior of America, is a plant with leaves rather thin and rather narrowly oblong-lanceolate, at length acuminated in a point more or less obtuse, rather distant along the stem so that they do not cover it. 
Ar. extremely interesting forn is found more commonly around the Gulf of St. Iavrence, in which the leaves, thick and broadly oval, are closely inbricuted along a stem which is itself generally more fleshy.

This extreme form, perhaps exclusively naritime, I propose to desiente as follows:

$$
\text { SIIATIMa STILATA (L.) Desf. ver. crassa n. var. }
$$

Sten thick; leave fleshy, inbricated on the sten, broadly ovil, sccrcely acuminate, somewhat rounded at apex.

QUEBEC: Nue Island, Winoan Archipelago, on an islet of the bird sanctuery; July 28, 1926; Victorin \& Rolland 24249; type in the Victorin Herbarium; cotypes in the University of Lontreal Herbarium and in the Gray Herbariun.--Alright Island, Magdalen Islands, sand ridge bordering the strand at the narrows; Aug. 21, 1912; Fernald et al. 7194.-Natashquan, North Coast, on the dunes of the coast south of the estuary; July 21, 1924; Victorin \& Rolland 18480.--Bouleaux Island, Mingan Archipelago, on the seashore; August 4, 1924; Victorin \& Rolland 18532.

NEW BRUNSWICK: Shediac; July 30, 1925; Knowlton.

pp. $80-86$

10. SMILACINA Desf. Ann. Mus. Paris 9:51. 1807. Salomonia Heist. Sust. 5. 1748. Vagnera Adans Fam. P1. 2:496. 1763. Tovaria Necker, Elem. 3: 190. 1790. Non Adanson (Tovara) 1763.

Polygonastrurn Hoench, Mieth. 637. 1794.

Sigillaria Raf. Journ. Phys. 89: 261. 1819. Asteranthe fium Kunth, Enum. P1. 5: 151. 1850. Jocaste Kunth, 1. c. 154. 1850. Medora Kunth, 1. c. 155. 1850. Neolexis Salisb. Gen. Pl. Fragm. 64. 1866. 
Plants vigorous, with spreading rhizomes, generally elongate and more or less thick. Stem simple. Leaves large, many-nerved, alternate. Flowers in a terminal raceme or panicle, small, white or greenish. Divisions of the perianth 6, spreading, equal, distinct nearly so. Stamens 6, inserted at the base of the perianth segments; filaments subulate; anthers introrse. Ovary 3-celled, each cell containing 2 ovules; style short; stigma 3-lobed. Berry globulár. Seeds 1-2, with thin seed-coat.

NOMENCLATURE. -- Probably a diminutive of Smilax, another genus of the Liliaceae, because of a more or less distant resemblance. The generic name Smilacina is a part of the list of nomina conservanda adopted by the Vienna Congress, and is retained here as such. Salomonia, which was applied by HEISTER to this plant, was prior to 1753, date chosen as the beginning of the nomenclature; it is uncertain besides. Tovaria (NECKER 1790) is not so doubtful (since NECKER cited the three Linnaean species of Convallaria which constitute the Smilacina of DESFONTA INES), however the description is faulty (perianth five-parted, berry l-celled, etc.) so that it is generally agreed to ignore it. Those who do not accept the International Rules of Vienna have generally adopted Vagnera Adanson.

GENERIC NOTES.--About 25 species proper in America and Asia.

ANALYTICAL KEY TO THE SPECIES.

Flowers in a panicle, numerous; woodland species ....... S. racemosa

Flowers in a simple raceme, less numerous; open places

Leaves $7-12$, sandy areas, shores ....2. S. stellata

Leaves 2-4, marshes and bogs. ....3. S. trifolia.

1. Smilacina racemosa (L.) Desf. Ann. Mus, Paris 9:51. 1807. 
Rhizome thick and fleshy, horizontal and elongate, with endotrophic mycorrhiza; stem (30-90 cm. long) a little angular, arcuate, finely puberulent above; leaves $(7-21 \mathrm{~cm}$. X 3-8 cm.) oblong-lanceolate or ovate, sessile or nearly so at maturity, finely puberulent below and sometimes above; panicle (3-12 cm. long) dense, many-flowered, pedunculate; flowers pedicellate; divisions of the perianth (2 mm. long) equalling the ovary; berry ( $5-6 \mathrm{~mm}$. in diameter) aromatic, red and marked with purple dots. (Fig. 23).

DISTRIBUTION. - Moist deciduous woods, Nova Scotia-British Columbia--Arizona--Georgia. Sometimes subspontaneous in Europe. Common through the West and South of suebec, also in the low grounds about the hills. Unknown about the Gulf of St. Lawrence, like many plants of its kind, and probably limited at the north by the great pine forest.

Forma foliosa Vict. Contrib. Lab. Bot. Univ. Montreal, 14: 15. 1929.--Lowest branch of the panicle in the axil of a leaf. Quebec (about the city of uebec, Victorin)--Nova Scotia, and probably throughout the region.

ECOLOGIE. - The rhizome of this species is a good example of subterannean sympodium, an example analogous to that furnished by Solomon's Seal. This rhizome, in effect, extends through the ground horizontally then abrumptly raises its extremity vertically, exposing to the air a branch bearing the leaves and the flowers. This aerial branch disappears at last in the autumn and is severed from the rhizome. But the axillary bud nearest the cicatrix develops then into a horizontal branch which prolongs the rhizome, and in the following spring straightens itself up and turns its extremity into the air. There is formed, therefore, a sort of subterranean sympodium, not, as in the case of stems which are wholly aerial, because the terminal bud aborts, but because all of the upper part of the aerial stem is destroyed each year. The scars permit the computation of the age of the part of the rhizome which is still functional; in proportion as the rhizome elongates at one end in growth, it is destroyed at the 
other, so that the entire plant slowly gives away and is replaced by the neighboring vegetation.

Except for the anthers, all parts of the flower are white, which makes the inflorescence quite conspicuous, much more so than that of Smilacina stellata. The individuals are not grouped into a colony like those of the latter species, but although isolated, are very numerous. The flowers are proterogynous, and cross fertilization is facilitated by the divergence of the stamens. (Robertsan).

FOLKLORE. - The Algonquins, according to D'Urban, called this plant Au-que-co-ce-wa.

2. Smilacina stellata (L.) Desf. Ann. Mus. Paris, 9:52. 1807.

Star Smilacina

Star-flowered False Solomon's Seal.

Rhizome thick and fleshy, horizontal, and more or less elongate; stem (20-50 cm. long) glabrous, erect; leaves (5-13 X 1-4 cm.) oblong-lanceolate or lanceolate, sessile and slightly clasping, lightly pubescent below, flat or slightly concave; flowers pedicellate, forming a cluster (25-50 mm. long) sessile or shortly pedunculate, several-flowered; divisions of the perianth (3-5 mm. long) oblong, obtuse; berry (6$10 \mathrm{~mm}$. diameter) at first green and marked by six black lines, at last wholly black. (Fig. 24).

DISTREBUTION. - Along the shores or sandy river flood-plains, almost al ways in open places, Newfoundland-Labrador-uebec-Lake Superior--British Columbia-California-Virginia. Sometimes subspontaneous in Europe. Also in the North of Europe. In uebec, frequent in its habitat along the Saint Lawrence and around the Bulf (All of North Coast, from the Seven Islands to White Sand, Magdalen Islands, Gaspe Region, etc.) In the districts of the east and further to the south it becomes a plant of marshes. 
Var. crassa Vict. Contrib. Lab. Bot. Univ. Montreal, 14:16. 1929.-- Stem thick; leaves fleshy, imbricated on the stem, broadly oval, scarcely or not at all acuminate at apex, with a somewhat rounded point. Around the Gulf of St. Lawrence (Mingan and Magdalen Islands, etc.) and sometimes in the interior. It is the halophytic form of the species.

ECOLOGY:--According to ecological factors, very variable as to the shape of the leaves, their size, and their texture.

The stem is strongly arcuate, and the flowers are disposed above in such away that the sepals are extended horizontally or nearly so. This position facilitates the access of the flower to insects hardly specialized, who are able to easily reach the nectar and the pollen. The flowers are proterogynous; when they first open the stigmas are receptive and the anthers closed. (ROBERTSON).

\section{Sililacina trifolia (L.) Desf. Apin. Mus. Paris,} 9: 52. 1807.

Three-leaved Smilacina.

Three-leaved False Solomon's Seal.

Plant smaller than the preceding species, glabrous, with scaly rhizomes trailing extensively through the Sphagnum, bearing two-leaved sterile shoots and 3-4 leaved fertile shoots. Stem scaly $(5-40 \mathrm{~cm}$. long); leaves ( $5-13 \mathrm{~cm} . X 1-4 \mathrm{~cm}$ ) sheathing, sessile, oval, oblong or oblong-lanceolate, acute or acuminate; flowers in an erect culster, few-flowered and pedunculate, often on a zigzag rachis; perianth-segments ( $3 \mathrm{~mm}$. long) oblong or oblong-lanceolate, obtuse, slightly reflexed at tip; berry dark red ( $5-6 \mathrm{~mm}$. in diameter), turning black on drying. (Fig. 25).

DISTRIBUTION.--Cold marshes and bogs, most of ten in Sphagnum moss, Newfoundland-Labrador--Quebec-Mackenzie--British Columbia-Minnesota-New Jersey. 
Also in Siberia. In wuebec, scattered from the extreme north (Ungava river, Spreadborough; Ungava Bay, Turner; Lake Mistassini, Macoun; Abitibi, Victorin) to the lower Laurentides, the districts of the Fast, and the Magdalen Islands. Outside of the subarctic region it is strictly confined to bogs.

NOTES.--The berries appear to be strongly cathartic, and certain traveling botanists of the subarctic region (Fernald, etc.) have used them with success in place of cascara. 